\title{
A RAPID AND EFFICIENT DNA EXTRACTION PROTOCOL FOR Ganoderma zonatum, A BASAL AND UPPER STEM ROT PATHOGEN OF OIL PALM IN MALAYSIA
}

\author{
JAYANTHI NAGAPPAN ${ }^{*}$; FAIZUN KADRI*; CHIN CHIEW FOAN**; RICHARD M COOPER ${ }^{\ddagger}$; \\ SEAN T MAY‡;; IDRIS ABU SEMAN* and ENG TI LESLIE LOW*
}

\begin{abstract}
Ganoderma zonatum is associated with both the basal and upper stem rot diseases in oil palm. Despite the severity of these diseases, there is only limited information on the molecular characteristics of this oil palm pathogen. Most of the studies on G. zonatum related to oil palm are focused on the epidemiology and genetic diversity of the organism. In other palm species, G. zonatum has also been identified as the causal agent of bud rot disease. To further characterise the organism using molecular techniques, the ability to isolate good quality DNA samples is important. In this study, seven DNA extraction protocols were evaluated and the best protocol, Boehm protocol, had the highest yield of good quality DNA. The protocol was able to yield $208.95 \pm 4.52 \mu \mathrm{g} D N A$ per gram of sample with purities above 1.80 for $A_{260 / 280}$ and 2.0 for $A_{260 / 230^{\circ}}$ This extraction protocol is a rapid and efficient protocol that employs cetyl trimethylammonium bromide (CTAB), sodium dodecyl sulphate (SDS), $\beta$-mercaptoethanol and proteinase $K$ in the lysis buffer. The Boehm protocol was further tested on three other Ganoderma species found in the oil palm plantations and a medicinal fungus, G. lucidum. It was noted that the protocol was efficient, with high yields for G. zonatum when compared to the other four species. This is probably due to the fact that extraction protocols for each organism requires specific optimisation to obtain optimal yield and purity. In conclusion, the Boehm protocol was best suited for genomic DNA extraction of G. zonatum and found suitable for downstream applications such as PacBio sequencing.
\end{abstract}

Keywords: basal stem rot, DNA extraction, Ganoderma zonatum, mycelium, upper stem rot.

Received: 8 November 2019; Accepted: 11 March 2020; Published online: 11 September 2020.

Malaysian Palm Oil Board,

6 Persiaran Institusi, Bandar Baru Bangi,

43000 Kajang, Selangor, Malaysia.

E-mail: lowengti@mpob.gov.my

** School of Biosciences, Faculty of Science, University of Nottingham Malaysia Campus, Jalan Broga, 43500 Semenyih, Selangor, Malaysia.

‡ Department of Biology and Biochemistry, University of Bath, Bath BA2 7AY, United Kingdom.

抹 Nottingham Arabidopsis Stock Centre, Division of Plant and Crop Sciences, School of Biosciences, University of Nottingham, Loughborough, United Kingdom.

\section{INTRODUCTION}

Ganoderma zonatum is a fungus that belongs to the phylum Basidiomycota, class Agaricomycetes, order Polyporales and family Ganodermataceae (Steyart, 1967). Ganoderma zonatum has been associated with basal stem rot (BSR) disease of oil palm in South-east Asia, a disease that has threatened the Malaysian oil palm industry with an export revenue of RM 65.12 billion (Kushairi et al., 2019). It is a well-known fact that BSR in Malaysia, Indonesia and Papua New Guinea (PNG) is caused predominantly by the pathogen Ganoderma boninense. Another Ganoderma 
species that was reported to cause BSR was G. miniatocinctum, while G. tornatum is a saprophyte that is found in oil palm plantations (Idris, 1999).

Idris (1999) reported the presence of both G. boninense and Ganoderma miniatocinctum was associated with the presence of Ganoderma zonatum in the oil palm plantations. Ganoderma zonatum was also reported to cause other diseases such as upper stem rot (USR) disease in Malaysia (Hassan et al., 2005; Rakib et al., 2014; 2017), Indonesia (Rees et al., 2012) and PNG (Pilotti, 2005). Rakib et al. (2015) found that $G$. zonatum from USR-infected palms tend to be more aggressive than G. zonatum from BSR-infected palms in Malaysia. On the contrary, G. boninense from BSR-infected palms were more aggressive than G. boninense from USR-infected palms. Here the different degree of aggressiveness was evaluated based on criteria such as area under disease progress curve (AUDPC), epidemic rate, severity of foliar symptoms, disease severity index (DSI), stem bole and primary root necrosis. As an example, the mean DSI recorded for G. zonatum of USR-infected palms $(6.84 \%)$ was significantly higher compared to BSR-infected palms $(2.39 \%)$ at 12 weeks after infection. In the USA, G. zonatum is also a lethal pathogen that causes butt rot in over 60 palm species (Elliott et al., 2018) and this is of great concern in Florida. The only way to curb the spread of butt rot is through prevention, as commonly practised in the USA (Elliott and Broschat, 2000).

Recently, Elliott et al. (2018) examined the genetic variability of $25 \mathrm{G}$. zonatum isolates infecting 12 different palm species in Florida and an additional 17 more isolates from eight different countries. The DNA were extracted using the Gentra ${ }^{\circledR}$ Puregen $^{\circledR}$ Cell Kit (Qiagen) (Elliott et al., 2018). As for G. zonatum in BSR (Rakib et al., 2017; Wong et al., 2012) and USR (Rakib et al., 2017) studies in oil palm, the DNA were extracted using DNeasy Mini Plant Kit (Qiagen). Numerous studies have highlighted that cell lysis efficiency, DNA yield and quality depend largely on sample type and protocols used (Gul et al., 2017; Nagi et al., 2013; Natarajan et al., 2016; Perry et al., 2014; Umesha et al., 2016). Most of the fungi studied to date require modifications to existing extraction protocols to produce good quality and high yield of nucleic acids (Motkova and Vytrasova, 2011; Nagappan et al., 2018; Verant et al., 2016). It is pertinent to establish the best extraction protocol for each fungus that is studied in depth. Moreover, it would be an added advantage if one DNA extraction protocol is feasible to be used across most fungi species or on closely related species.

It would be beneficial to be able to go a step further to study any organism at the nucleotide level (Choi and Kim, 2017; Li et al., 2018). In order for any sequencing project to proceed, such as PacBio sequencing, large amount of good purity DNA is required to meet this requirement. Usage of extraction kit is not suitable as it yields low amount of DNA and is not cost-effective (Pipan et al., 2018; Psifidi et al., 2015; Umesha et al., 2016). Thus, the current study explored and recommend a time efficient and cost-effective DNA extraction protocol of G. zonatum found in the oil palm plantations in Malaysia. Here, we presented a rapid and suitable DNA extraction protocol with minimal amount of tissues required to produce high yields of good purity DNA.

\section{MATERIALS AND METHODS}

\section{Biological Materials}

Ganoderma zonatum, G. boninense, G. miniatocinctum and G. tornatum stocks were obtained from the GanoDROP Unit, Biology Division, Malaysian Palm Oil Board (MPOB), Malaysia. The fruiting body of G. lucidum was purchased from the Cepaul Mushroom Nursery, Kajang, Selangor, Malaysia. Actively growing eight day old mycelia were transferred into $250 \mathrm{ml}$ of Potato Dextrose Broth and incubated at $27 \pm 1^{\circ} \mathrm{C}$ for 14 days. The cultures were harvest and washed with sterilised distilled water and frozen in liquid nitrogen prior to DNA extraction.

\section{Genomic DNA Isolation of Ganoderma Species}

A total of seven protocols were tested for genomic DNA isolation of G. zonatum. The first and second protocol used cetyl trimethylammonium bromide (CTAB) (Voigt et al., 1999) and sodium dodecyl sulphate (SDS) (Moslem et al., 2010) extraction buffers, respectively. The third protocol tested, as described by Kim et al. (1997) used polyvinylpyrrolidone (PVP) and SDS, whereby, the subsequent protocol also applied SDS as one of the components in the extraction buffer (Weiland, 1997). The fifth protocol was an online protocol by Vilgalys (2018), whereby he applied a 2 X CTAB extraction buffer. The second last extraction protocol investigated, employed Triton X-100 and SDS as the lysis buffer (Extraction method 1: Van Burik et al., 1998). The final protocol employed a combination of CTAB, SDS, $\beta$-mercaptoethanol and proteinase K (Boehm, 2004). RNAse was added in all the protocols evaluated. All the protocols explored were described using the respective author's name for easy identification. The quantity and quality of extracted nucleic acids were measured using Nanodrop $^{\mathrm{TM}} 1000$ Spectrophotometer.

\section{Analysis of DNA by Agarose Gel Electrophoresis}

The quality and size of DNA was determined on $0.8 \%(\mathrm{w} / \mathrm{v})$ agarose gel in $1 \times$ TAE buffer $(40 \mathrm{mM}$ Tris, $20 \mathrm{mM}$ acetic acid, and $1 \mathrm{mM}$ EDTA), which was 
precast with $3 \mu \mathrm{l}$ of EtB 'Out' nucleic acid staining solution (Yeastern Biotech Co., Ltd). Two microlitres (50 ng $\mu^{-1}$ ) of sample were loaded into each lane. Electrophoresis was performed at $80 \mathrm{~V}$ for $40 \mathrm{~min}$ and the agarose gel was post-stained with the same staining solution for $10 \mathrm{~min}$. The agarose gel was visualised using the G:BOX Chemi XX9 (Syngene).

\section{Statistical Analysis}

All extractions were performed in triplicates to account for variability. One way analysis of variance (ANOVA) was used to determine statistical differences of DNA yield between protocols using a significance level of $\mathrm{P}<0.05$. A T-test was used to compare mean DNA yield between two protocols. Data are shown as the mean \pm SD.

\section{Polymerase Chain Reaction (PCR) Amplification}

To verify the quality of the extracted DNA, the DNA was used as a template in a PCR experiment to amplify a microsatellite region, as described by Merciere et al. (2015). The size of DNA was determined on $4.0 \%(\mathrm{w} / \mathrm{v})$ Super Fine Resolution (SFR) agarose gel in $1 \times$ TAE buffer (40 mM Tris, $20 \mathrm{mM}$ acetic acid, and $1 \mathrm{mM}$ EDTA), which was precast with $12.5 \mu \mathrm{l}$ of EtB 'Out' nucleic acid staining solution (Yeastern Biotech Co., Ltd). Six microlitres of PCR product were loaded into each lane. Electrophoresis was performed at $100 \mathrm{~V}$ for 3 $\mathrm{hr}$ and the SFR agarose gel was post-stained with the same staining solution for $10 \mathrm{~min}$. The agarose gel was visualised using the G:BOX Chemi XX9 (Syngene).

\section{RESULTS AND DISCUSSION}

In the process of identifying the best DNA extraction protocol for G. zonatum, seven protocols were evaluated on this pathogen that is associated with BSR, USR and butt rot. Six protocols that were evaluated have been used on fungi from different phylum such as Basidiomycota, Ascomycota, Zygomycota, Deuteromycota and Oomycota. The seventh protocol (Kim protocol) is a simple and rapid protocol used to extract DNA from fruit trees and conifers that have high levels of polyphenols. This protocol was selected as high level of polyphenols have been reported in Ganoderma lucidum (Dong et al., 2019) and was thought to be suitable for G. zonatum. We also included a commonly used protocol, CTAB as a positive control in this study.

The starting mycelial weight used in these seven protocols was $0.1 \mathrm{~g}$ and the amount of DNA recovered ranged from $\sim 13-\sim 260 \mu \mathrm{g} \mathrm{DNA} \mathrm{g}^{-1}$ of sample (Table 1). The integrities of the extracted DNA were separated and observed in $0.8 \%$ agarose gel (Figure 1). All the seven protocols were able to extract intact high molecular weight genomic DNA. The bands from the Moslem and Kim protocols in lanes 2 and 3, respectively appeared to be brighter with a slight smear, indicating some levels of DNA contamination has occurred. The protocol that produced the highest yield recorded from this study was with the Van Burik protocol that used a combination of two components in the lysis buffer. In this protocol, the application of Triton X-100 and SDS were capable of disrupting the fungal cell wall and membrane wall producing a yield of $259.77 \pm$ $6.67 \mu \mathrm{g} \mathrm{DNA} \mathrm{g}{ }^{-1}$ of sample, which is significantly higher $(\mathrm{P}<0.05)$ compared to the other six protocols. However, the average purity for $A_{260 / 230}$ was way below the standard absorbance ratio of 2.0 and above. The average absorbance ratio of $\mathrm{A}_{260 / 230}$ measured by Nanodrop was $0.89 \pm 0.05$, which indicates high levels of polysaccharides detected in the extracted DNA.

The protocols by Kim, Vilgayls, Weiland and Moslem also had high levels of polysaccharide contamination, with low absorbance ratios between $0.26 \pm 0.01$ to $1.14 \pm 0.04$ for $A_{260 / 230}$. These are indications of the presence of contaminant biomolecules. These protocols also had exceptionally low yields, between $12.67 \pm 0.03$ to $65.17 \pm 2.00 \mu \mathrm{g}$ DNA ${ }^{-1}$ of sample. The results demonstrated that the lysis buffers employed were not sufficient in breaking down the cell and membrane walls of $G$. zonatum. On the contrary, the Boehm protocol with a mixture of several components such as CTAB, SDS, $\beta$-mercaptoethanol and proteinase $K$ in the buffer was able to remove contaminated biomolecules such as proteins, carbohydrates, lipids or other nucleic acids, producing absorbance ratios of 2.14 and 2.22 for $\mathrm{A}_{260 / 280}$ and $\mathrm{A}_{260 / 230}$ respectively. The expected ratios of $A_{260 / 280}$ and $A_{260 / 230}$ for 'pure' DNA are commonly within the range of $1.8-2.0$ and $2.0-2.2$ (Seo et al., 2011; Lucena-Aguilar et al., 2016). It was notable that this protocol produced a yield of $208.95 \pm 4.52 \mu \mathrm{g}$ DNA g ${ }^{-1}$ of sample, which was only a reduced yield of $\sim 50 \mu \mathrm{g} \mathrm{DNA} \mathrm{g}^{-1}$ of sample when compared to the van Burik protocol. The combination of components in this buffer were extremely efficient in the lysis of cell wall and cell membrane of G. zonatum. Due to the anionic and cationic conditions of SDS and $\mathrm{CTAB}$, these buffers work well with each other in solubilising proteins and lipids (Tripathy et al., 2017). Generally, Ganoderma species contains $\beta$-glucans as the major active polysaccharides (Obodai et al., 2017) and are rich in phenolic compounds from fruiting bodies and mycelia (Mishra et al., 2018). The inclusion of $\beta$-mercaptoethanol with SDS and CTAB aided in the breaking of disulfide bonds between the cysteine residue present in the crude extract (Wingfield, 2001; Winther and Thorpe, 2014). Furthermore, $\beta$-mercaptoethanol is an antioxidant that is commonly used to address issues related to 
phenolics (Calderon-Cortes et al., 2010; Sahu et al., 2012). Meanwhile, proteinase $K$ which works better in the presence of SDS, inactivates DNases and leaves the DNA complete and intact. This suggests that the DNA extracted by the Boehm protocol was able to produce good quality DNA for G. zonatum. The Boehm protocol was reported by Gracia et al. (2014), where it was applied as a modification to the existing Moller protocol to produce good quality DNA from two fungal pathogens of alfalfa, Phoma medicaginis and Colletotrichum trifolii that was suitable for internal transcribe spacer sequencing.

The commonly used Voigt (CTAB) protocol also produced good quality DNA in terms of absorbance ratio of $\mathrm{A}_{260 / 280}$ and $\mathrm{A}_{260 / 230}$ (Table 1). Nevertheless, the yield was $2.4 \mathrm{x}$ lower with $87.32 \pm 5.21 \mu \mathrm{g}$ DNA $\mathrm{g}^{-1}$ of sample when compared to the Boehm protocol. Albeit, the Voigt protocol is still viable but the drawback to this protocol is that additional material is required to achieve higher yields of DNA and it is labour intensive. The duration required for the Voight protocol is two days, in contrast to the Boehm protocol which takes approximately 4 $\mathrm{hr}$ from the beginning of the process until DNA is ready for use. Time is of the essence especially when a large number of samples are needed to be tested or sequenced.
To further assess the reliability of the Boehm extraction protocol and attest on the viability of one protocol used across closely related fungi species, the three Ganoderma species that were found in oil palm plantations and one reference species, G. lucidum were evaluated. It was noted that G. boninense, G. miniatocinctum, G. tornatum and G. lucidum produced rather low yields compared to G. zonatum, ranging from $33.40 \pm 1.25$ to $89.83 \pm 1.26 \mu \mathrm{g} \mathrm{DNA} \mathrm{g}^{-1}$ of sample (Table 2). Nevertheless, the G. miniatocinctum DNA was of good quality, with absorbance ratios of $2.04 \pm 0.02$ and $2.00 \pm 0.02$ for $\mathrm{A}_{260 / 280}$ and $\mathrm{A}_{260 / 230}$, suggesting that the sample is free from proteins and polysaccharide compounds. In Figure 2, G. boninense and G. lucidum are shown to have bands with higher intensity compared to the other Ganoderma species. This could be due to the presence of carbohydrates, lipids, salts or phenol that absorb strongly at $230 \mathrm{~nm}$ (Lucena-Aguilar et al., 2016). The results correlate well with the $\mathrm{A}_{260 / 230}$ absorbance ratio as presented in Table 2. Kuhad et al. (2004) concluded that the selection of extraction buffers such as CTAB or SDS is fungus-specific when tested with six species of basidiomycetes. Hence, with further optimisation, the Boehm protocol could be suitable for use as a standard extraction protocol for closely related species though the yield produced is low.

TABLE 1. GENOMIC DNA YIELD AND QUALITY OF G. zonatum EXTRACTED FOLLOWING SEVEN PROTOCOLS

\begin{tabular}{|c|c|c|c|c|c|c|}
\hline Protocols & Duration & Parameters & Replicate 1 & Replicate 2 & Replicate 3 & Average \\
\hline \multirow[t]{3}{*}{ Voigt } & $\sim 2$ days & $\mathrm{A} 260 / 280$ & 1.90 & 1.92 & 1.91 & $1.91 \pm 0.01$ \\
\hline & & A260/230 & 1.93 & 1.77 & 1.85 & $1.85 \pm 0.08$ \\
\hline & & $\mu \mathrm{g} \mathrm{DNA} \mathrm{g}^{-1}$ sample & 81.50 & 91.55 & 88.90 & $87.32 \pm 5.21^{\mathrm{a}}$ \\
\hline \multirow[t]{3}{*}{ Moslem } & $\sim 2 \mathrm{hr}$ & A260/280 & 1.75 & 1.71 & 1.76 & $1.74 \pm 0.03$ \\
\hline & & A260/230 & 1.18 & 1.10 & 1.15 & $1.14 \pm 0.04$ \\
\hline & & $\mu \mathrm{g} \mathrm{DNA} \mathrm{g}^{-1}$ sample & 49.59 & 53.28 & 50.49 & $51.12 \pm 1.92^{\mathrm{b}}$ \\
\hline \multirow[t]{3}{*}{ Kim } & $\sim 4 \mathrm{hr}$ & A260/280 & 1.11 & 1.09 & 1.12 & $1.11 \pm 0.02$ \\
\hline & & A260/230 & 0.27 & 0.26 & 0.25 & $0.26 \pm 0.01$ \\
\hline & & $\mu \mathrm{g} \mathrm{DNA} \mathrm{g}^{-1}$ sample & 12.69 & 12.63 & 12.69 & $12.67 \pm 0.03^{c}$ \\
\hline \multirow[t]{3}{*}{ Weiland } & $\sim 3 \mathrm{hr}$ & A260/280 & 1.65 & 1.64 & 1.65 & $1.65 \pm 0.01$ \\
\hline & & $\mathrm{A} 260 / 230$ & 1.14 & 1.13 & 1.12 & $1.13 \pm 0.01$ \\
\hline & & $\mu \mathrm{g} \mathrm{DNA} \mathrm{g}^{-1}$ sample & 58.55 & 58.40 & 59.20 & $58.72 \pm 0.43^{\mathrm{d}}$ \\
\hline \multirow[t]{3}{*}{ Vilgalys } & $\sim 2$ days & A260/280 & 1.99 & 1.98 & 1.97 & $1.98 \pm 0.01$ \\
\hline & & A260/ 230 & 1.28 & 1.17 & 1.15 & $1.20 \pm 0.07$ \\
\hline & & $\mu \mathrm{g} \mathrm{DNA} \mathrm{g}^{-1}$ sample & 63.15 & 65.20 & 67.15 & $65.17 \pm 2.00^{\mathrm{d}}$ \\
\hline \multirow[t]{3}{*}{ Van Burik } & $\sim 4 \mathrm{hr}$ & A260/280 & 1.83 & 1.78 & 1.80 & $1.80 \pm 0.03$ \\
\hline & & A260/230 & 0.94 & 0.86 & 0.86 & $0.89 \pm 0.05$ \\
\hline & & $\mu \mathrm{g} \mathrm{DNA} \mathrm{g}^{-1}$ sample & 267.30 & 254.60 & 257.40 & $259.77 \pm 6.67^{\mathrm{e}}$ \\
\hline \multirow[t]{3}{*}{ Boehm } & $\sim 4 \mathrm{hr}$ & $\mathrm{A} 260 / 280$ & 2.14 & 2.14 & 2.14 & $2.14 \pm 0.00$ \\
\hline & & A260/230 & 2.26 & 2.17 & 2.22 & $2.22 \pm 0.05$ \\
\hline & & $\mu \mathrm{g} \mathrm{DNA} \mathrm{g}^{-1}$ sample & 204.70 & 213.70 & 208.45 & $208.95 \pm 4.52^{f}$ \\
\hline
\end{tabular}

Note: Means \pm standard deviation (S.D.) in a column between protocols with different superscripts differ significantly $(\mathrm{P}<0.05)$.

Data are presented as mean \pm S.D. of three biological replicates. 
Next, we also assessed the integrity of the extracted DNA of G. zonatum across the seven protocols and also on the selected Boehm protocol on the five Ganoderma species. This was performed with PCR using Simple Sequence Repeat (SSR) primer pair that has an amplicon size of $150 \mathrm{bp}$. Firstly, we conducted experiments that showed PCR amplification of the extracted DNA from all the seven protocols (Figure 3). Despite disparity between the purity and concentrations of DNA, PCR amplification was successful from the seven protocols evaluated (Pipan et al., 2018). Apart from DNA quality and concentration, there are many factors to consider when assessment is

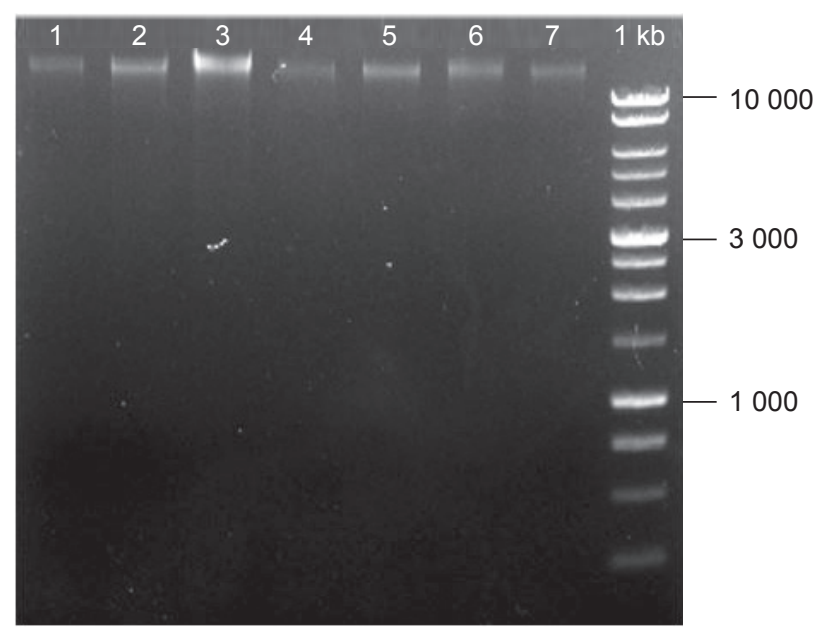

Figure 1. Agarose gel electrophoresis of extracted genomic DNA. Two microlitres of sample (50 $\mathrm{ng} \mathrm{ul}^{-1}$ ) were loaded into each lanes. Ganoderma zonatum extracted with seven published protocols: 1) Voigt, 2) Moslem, 3) Kim, 4) Weiland, 5) Vilgalys, 6) Van Burik and 7) Boehm. based on PCR, such as suitability of primers, quality of reagents or even the thermal cycler used. Nevertheless, it is important to note that the Boehm protocol was able to produce the highest yield of highly pure DNA, making it suitable for most molecular biology applications. DNA from the five Ganoderma species extracted using the Boehm protocol was also suitable for PCR amplification (Figure 4). Nevertheless, the SSR band from the G. lucidum DNA was less intense compared to the amplicons from the other species. This is probably due to the lower quality of DNA produced from G. lucidum (Table 2).

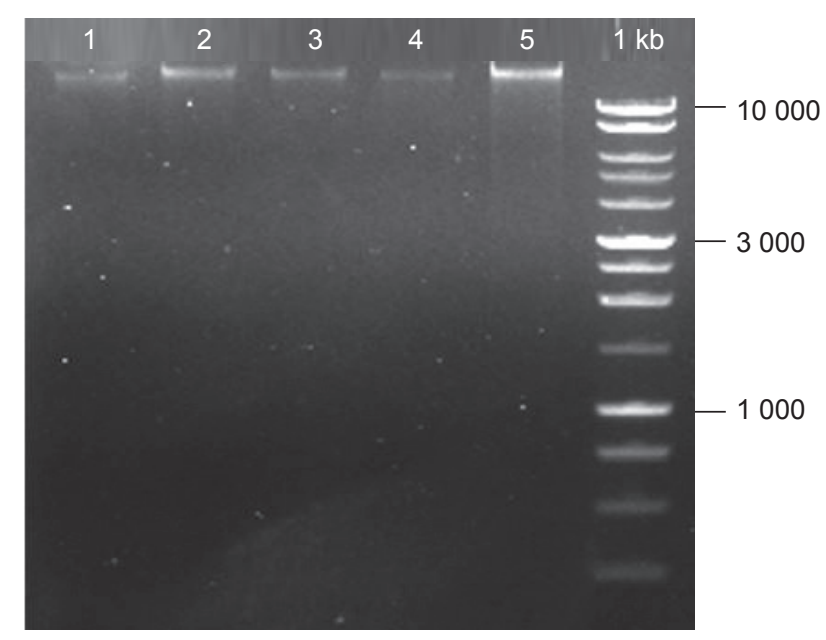

Figure 2. Agarose gel electrophoresis of extracted genomic DNA. Two microlitres of sample (50 $\mathrm{ng} \mathrm{ul}^{-1}$ ) were loaded into each lanes. Ganoderma species tested with the Boehm protocols were: 1) Ganoderma zonatum, 2) G. boninense, 3) G. miniatocinctum, 4) G. tornatum and 5) G. lucidum.

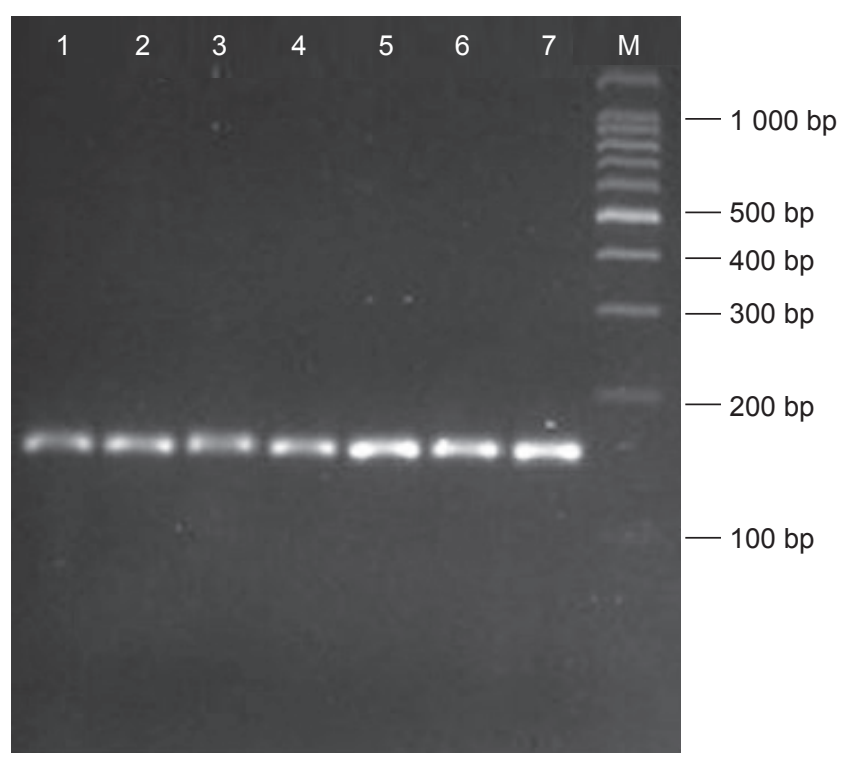

Figure 3. Agarose gel electrophoresis of genomic DNA. Polymerase chain reaction products of amplified microsatellite regions of Ganoderma zonatum extracted with seven published protocols: 1) Voigt, 2) Moslem, 3) Kim, 4) Weiland, 5) Vilgalys, 6) Van Burik, 7) Boehm and M-100 bp DNA ladder. 


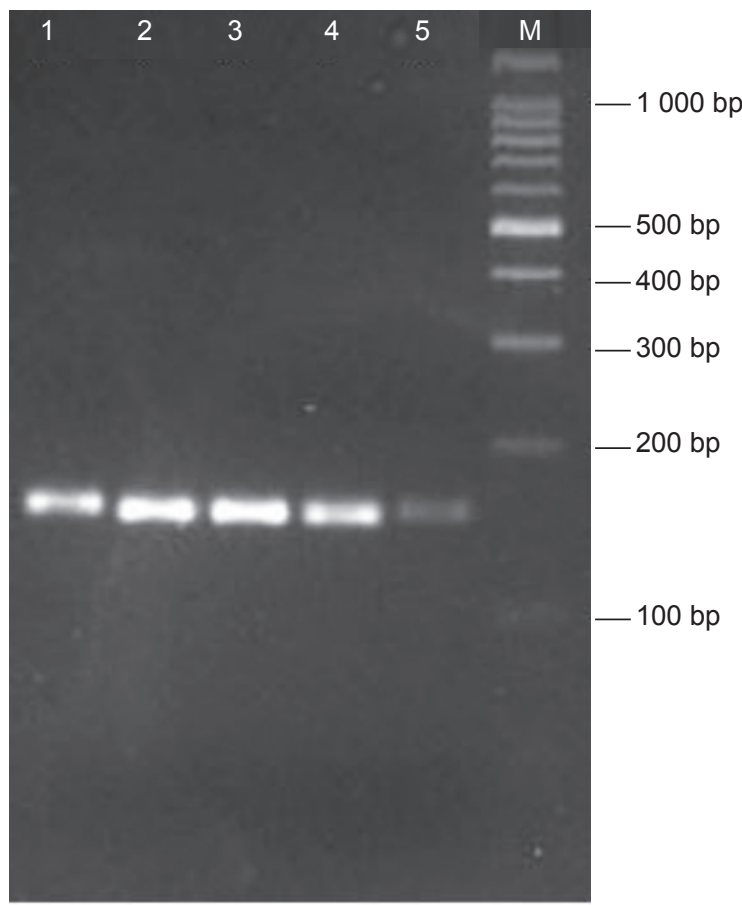

Figure 4. Agarose gel electrophoresis of genomic DNA. Polymerase chain reaction products of amplified microsatellite regions of Ganoderma species extracted via the Boehm protocol. Lane 1-5: Ganoderma zonatum, G. boninense, G. miniatocinctum, G. tornatum, G. lucidum and M-100 bp DNA ladder.

TABLE 2. GENOMIC DNA YIELD AND QUALITY OF FIVE Ganoderma SPECIES EXTRACTED VIA BOEHM (2004) PROTOCOL

\begin{tabular}{|c|c|c|c|c|c|}
\hline Species & Parameters & Replicate 1 & Replicate 2 & Replicate 3 & Average \\
\hline \multirow[t]{3}{*}{ G. zonatum } & $\mathrm{A}_{260 / 280}$ & 2.14 & 2.14 & 2.14 & $2.14 \pm 0.00$ \\
\hline & $\mathrm{A}_{260 / 230}$ & 2.26 & 2.22 & 2.17 & $2.22 \pm 0.05$ \\
\hline & $\mu \mathrm{g} \mathrm{DNA} \mathrm{g}^{-1}$ sample & 204.70 & 208.45 & 213.70 & $208.95 \pm 4.52$ \\
\hline \multirow[t]{3}{*}{ G. boninense } & $\mathrm{A}_{260 / 280}$ & 1.99 & 1.97 & 2.09 & $2.02 \pm 0.06$ \\
\hline & $\mathrm{A}_{260 / 230}$ & 1.69 & 1.60 & 1.55 & $1.61 \pm 0.07$ \\
\hline & $\mu \mathrm{g} \mathrm{DNA} \mathrm{g}^{-1}$ sample & 41.35 & 41.40 & 41.70 & $41.48 \pm 0.19$ \\
\hline \multirow[t]{3}{*}{ G. miniatocinctum } & $\mathrm{A}_{260 / 280}$ & 2.02 & 2.05 & 2.05 & $2.04 \pm 0.02$ \\
\hline & $\mathrm{A}_{260 / 230}$ & 2.02 & 2.00 & 1.98 & $2.00 \pm 0.02$ \\
\hline & $\mu \mathrm{g} \mathrm{DNA} \mathrm{g}^{-1}$ sample & 65.00 & 65.00 & 66.05 & $65.35 \pm 0.61$ \\
\hline \multirow[t]{3}{*}{ G. tornatum } & $\mathrm{A}_{260 / 280}$ & 2.03 & 2.01 & 2.03 & $2.02 \pm 0.01$ \\
\hline & $\mathrm{A}_{260 / 230}$ & 1.80 & 1.73 & 1.69 & $1.74 \pm 0.06$ \\
\hline & $\mu \mathrm{g} \mathrm{DNA} \mathrm{g}^{-1}$ sample & 88.65 & 89.70 & 91.15 & $89.83 \pm 1.26$ \\
\hline \multirow[t]{3}{*}{ G. lucidum } & $\mathrm{A}_{260 / 280}$ & 1.90 & 1.83 & 1.81 & $1.85 \pm 0.05$ \\
\hline & $\mathrm{A}_{260 / 230}$ & 1.46 & 1.35 & 1.21 & $1.34 \pm 0.13$ \\
\hline & $\mu \mathrm{g}^{\mathrm{DNA}} \mathrm{g}^{-1}$ sample & 34.40 & 32.00 & 33.80 & $33.40 \pm 1.25$ \\
\hline
\end{tabular}

Note: Data are presented as mean \pm S.D. of three biological replicates.

\section{CONCLUSION}

The Boehm protocol was the most efficient, simple and reliable DNA extraction protocol tested on the mycelium of G. zonatum. This protocol eliminates the use of phenol and requires very low amount of tissue to produce high yield and good quality DNA. It takes about $4 \mathrm{hr}$ to complete the procedure compared to the commonly used
CTAB protocol which takes approximately two days. The evaluation of protocols was aimed at obtaining good quality DNA for downstream applications, such as PacBio sequencing. Therefore, for approaches such as PacBio or Southern blot analysis which normally require large quantity and good quality DNA (Nagappan et al., 2018), the short duration of the Boehm protocol was able to achieve that. 


\section{ACKNOWLEDGEMENT}

The authors would like to thank the DirectorGeneral of MPOB for permission to publish this article. A special appreciation is extended to the Biomarker Discovery Group members of MPOB for usage of their laboratory. Jayanthi Nagappan and Faizun Kadri conducted laboratory experiments. Leslie Low Eng Ti, Chin Chiew Foan, Richard M Cooper and Sean T May conceptualised the research study and proof read the article. Idris Abu Seman provided the fungal samples.

\section{REFERENCES}

Boehm, E W (2004). Fungal genomic DNA extraction. http: / / www.protocol-online.org / prot/ Protocols / Fungal-Genomic-DNA-Extraction-1200.html, accessed on 1 March 2019.

Calderon-Cortes, N; Quesada, M; Cano-Camacho, $\mathrm{H}$ and Zavala-Paramo, G (2010). A simple and rapid method for DNA isolation from xylophagous insects. Int. J. Mol. Sci., 11(12): 5056-5064.

Choi, J J and Kim, S-H (2017). A genome tree of life for the fungi kingdom. PNAS, 114(35): 9391-9396.

Dong, Q; He, D; Ni, X; Zhou, H and Yang, H (2019). Comparative study on phenolic compounds, triterpenoids and antioxidant activity of Ganoderma lucidum affected by different drying methods. J. Food Meas. Charact., 13(4): 3198-3205.

Elliott, M L and Broschat, T K (2000). Ganoderma butt rot of palms. https: / / edis.ifas.ufl.edu / pdffiles / PP / PP10000.pdf, accessed on 1 November 2018.

Elloitt, M L; Des Jardin, E A; Ortiz, J V and Macias, T (2018). Genetic variability of Ganoderma zonatum infecting palms in Florida. Mycologia, 110(2): 339-346.

Gracia, A N; Ayub, N D; Fox, A R; Gomez, M C; Dieguez, M J; Pagano, E M; Berini, C A; Muschietti, J P and Soto, G (2014). Alfalfa snakin-1 prevents fungal colonization and probably coevolved with rhizobia. BMC Plant Biology, 14(1): 248-260.

Gul, F; Hussain, A; Jan, G and Hamayun, M (2017). Genomic DNA extraction for molecular identification of endophytic fungi: An easy and efficient protocol. Biosci. Biotech. Res. Asia, 14(2): 667-671.

Hassan, Y; Foster, H L and Flood, J (2005). Investigations on the causes of upper stem rot (USR) on standing mature oil palms. Mycopathologia, 159(1): 109-112.
Idris, A S (1999). Basal Stem Rot (BSR) of Oil Palm (Elaeis guineensis Jacq.) in Malaysia: Factors Associated with Variation in Disease Severity. Ph.D thesis. Wye College, United Kingdom.

Kim, C S; Lee, C H; Shin, J S; Chung, Y S and Hyung, N I (1997). A simple and rapid method for isolation of high quality genomic DNA from fruit trees and conifers using PVP. Nucleic Acids Res., 25(5): 10851086.

Kuhad, R C; Kapoor, R K and Lal, R (2004). Improving the yield and quality of DNA isolated from white-rot fungi. Folia Microbiol., 49(2): 112-116.

Kushairi, A; Ong-Abdullah, M; Nambiappan, B; Hishamuddin, E; Bidin, M N I Z; Ghazali, R; Subramaniam, V; Sundram, S and Parveez, G K A (2019). Oil palm economic performance in Malaysia and R\&D progress in 2018. J. Oil Palm Res. Vol. 31(2): 165-194.

Li, H; Wu, S; Ma, X; Chen, W; Zhang, J; Duan, S; Gao, Y; Kui, L; Huang, W; Wu, P; Shi, R; Li, Y; Wang, Y; Li, J; Gua, X; Luo, X; Li, Q; Xiong, C; Liu, H; Gui, M; Sheng, J and Dong, $Y$ (2018). The genome sequence of 90 mushrooms. Sci. Rep., 8(1): 9982-9986.

Lucena-Aguilar, G; Sanchez-Lopez, A M; BarberanAceituno, C; Carrillo-Avial, J A; Lopez-Guerrero, J A and Aguilar-Quesada, R (2016). DNA source selection for downstream applications based on DNA quality indicators analysis. Biopreserv. Biobank., 14(4): 264-270.

Merciere, M; Laybats, A; Carasco-Lacombe, C; Tan, J S; Klopp, C; Durand-Gasselin, T; Alwee, S S R S; Camus-Kulandaivelu, L and Breton, F (2015). Identification and development of new polymorphic microsatellite markers using genome assembly for Ganoderma boninense, causal agent of oil palm basal stem rot disease. Mycol. Prog., 14(11): 103-113.

Mishra, J; Joshi, A; Rajput, R; Singh, K; Bansal, A and Misra, K (2018). Phenolic rich fractions from mycelium and fruiting body of Ganoderma lucidum inhibit bacterial pathogens mediated by generation of reactive oxygen species and protein leakage and modulate hypoxic stress in HEK 293 cell line. Advances in Pharmacological Sciences, 2018: 6285615.

Moslem, M A; Bahkali, A H; Abd-Elsalam, K A and Wit, P J G M (2010). An efficient method for DNA extraction from Cladosporioid fungi. Genet. Mol. Res., 9(4): 2283-2291.

Motkova, P and Vytrasova, J (2011). Comparison methods for isolating fungal DNA. Czech J. Food Sci., 29(Special Issue): S76-S85. 
Nagappan, J; Chin, C F; Angel, L P L; Cooper, R M; May, S T and Low, E T L (2018). Improved nucleic acid extraction protocols for Ganoderma boninense, G. miniatocinctum and G. tornatum. Biotechnol. Lett., 40(2): 1541-1550.

Nagi, M A; Abd-Elsalam, K A; Bahkali, A H and Mongy, A A A (2013). Improved method for DNA isolation from different types of soil infested with three fungal genera. Rom. Agric. Res., 30: 229333.

Natarajan, V P; Zhang, X; Morono, Y; Inagaki, F and Wang, F (2016). A modified SDS-based DNA extraction method for high quality environmental DNA from seafloor environments. Front. Microbiol., 7(986): 1-13.

Obodai, M; Mensah, D L N; Fernandes, A; Kortei, N K; Dzomeku, M; Teegarden, M; Schwartz, S J; Barros, L; Prempeh, J; Takli, R K and Ferreira, I C F R (2017). Chemical characterization and antioxidant potential of wild Ganoderma species from Ghana. Molecules, 22(2): 196-213.

Perry, M D; White, P L and Barnes, R A (2014). Comparison of four automated nucleic acid extraction platforms from the recovery of DNA from Aspergillus fumigatus. J. Med. Microbiol., 63(9): 1160-1166.

Pilotti, C A (2005). Stem rots of oil palm caused by Ganoderma boninense: Pathogen, biology and epidemiology. Mycopathologia, 159(1): 129-137.

Pipan, B; Zupancic, M; Blatnik, E; Dolnicar, P and Meglic, V (2018). Comparison of six genomic DNA extraction methods for molecular downstream applications of apple tree (Malus X domestica). Cogent Food and Agriculture, 4(1): 1540094.

Psifidi, A; Dovas, C I; Bramis, G; Lazou, T; Russel, C L; Arsenos, G and Banos, G (2015). Comparison of eleven methods for genomic DNA extraction suitable for large-scale whole-genome genotyping and long-term DNA banking using bold samples. PLOS ONE, 10(1): e0115960.

Rakib, M R M; Bong, C F J; Khairulmazmi, A and Idris, A S (2014). Genetic and morphological diversity of Ganoderma species isolated from infected oil palms (Elaeis guineensis). Int. J. Agric. Biol., 16(4): 691-699.

Rakib, M R M; Bong, C F J; Khairulmazmi, A and Idris, A S (2015). Aggressiveness of Ganoderma boninense and $G$. zonatum isolated from upper and basal stem rot of oil palm (Elaeis guineensis) in Malaysia. J. Oil Palm Res. Vol. 27(3): 229-240.
Rakib, M R M; Bong, C F J; Khairulmazmi, A; Idris, A S; Jalloh, M B and Wahida, N H (2017). Ganoderma species of basal and upper stem rots in oil palm (Elaeis guineensis) in Sarawak, Malaysia. J. Academia UiTM, 5: 27-35.

Rees, R W; Flood, J; Hasan, Y; Wills, M A and Cooper, R M (2012). Ganoderma boninense basidiospores in oil palm plantations: Evaluation of the possible role in stem rots of Elaeis guineensis. Plant Pathol., 61(3): 567-578.

Sahu, S K; Thangaraj, M and Kathiresan, K (2012). DNA extraction protocol for plants with high levels of secondary metabolites and polysaccharides without using liquid nitrogen and phenol. ISRN Mol. Biol., 2012: 205049.

Seo, A N; Kim, J-H; Lee, D; Jeong, J Y and Park, J-Y (2011). Comparison of the DNA preservation in neutral-buffered formalin fixed paraffin-embedded tissue and in non-buffered formalin fixed paraffinembedded tissue. Korean J. Pathol., 45(6): 549-556.

Steyaert, R L (1967). Les Ganoderma palmicoles. Bull. Jar. Bot. Nat. Belg., 37(4): 465-492.

Tripathy, S K; Maharana, M; Ithape, D M; Lenka, D; Mishra, D; Prusti, A; Swain, D; Mohanty, M R and Raj, K R R (2017). Exploring rapid and efficient protocol for isolation of fungal DNA. Int. J. Curr. Microbiol. App. Sci., 6(3): 951-960.

Umesha, S; Manukumar, H M and Raghava, S (2016). A rapid protocol for isolation of genomic DNA from food-borne fungal pathogens. 3 Biotech., 6(2): 123-131.

Van Burik, J A H; Schreckhise, R W; White, T C and Bowden, R A (1998). Comparison of six extraction techniques for isolation of DNA from filamentous fungi. Med. Mycol., 36(5): 299-303.

Verant, M L; Bohuski, E A; Lorch, J M and Blehert, D S (2016). Optimization methods for total nucleic acid extraction and quantification of the bat white-nose syndrome fungus, Pseqdogymnoascus destructans, from swab and environmental samples. J. Vet. Diagn. Invest., 28(2): 110-118.

Vilgalys Lab (2018). http://www.umich.edu/ $\sim$ mycology/protocols_assets / DNAminipreps.doc, accessed on 14 February 2018.

Voigt, K; Cigelnik, E and O'Donnell, K (1999). Phylogeny and PCR identification of clinically important Zygomycetes based on nuclear ribosomal-DNA sequence data. J. Clin. Microbiol., 37(12): 3957-3964. 
Weiland, J J (1997). Rapid procedure for the extraction of DNA from fungal spores and mycelia. Fungal Genet. Rep., 44(22): 1-7.

Wingfield, P T (2001). Use of protein folding reagents. Curr. Protoc. Protein Sci., 00(1): A.3A.1A.3A.4.
Winther, J R and Thorpe, C (2014). Quantification of thiols and disulfides. Biochim. Biophys. Acta, 1840(2): 383-346.

Wong, L C; Bong, C F J and Idris, A S (2012). Ganoderma species associated with basal stem rot disease of oil palm. Am. J. Appl. Sci., 9(6): 879-885.

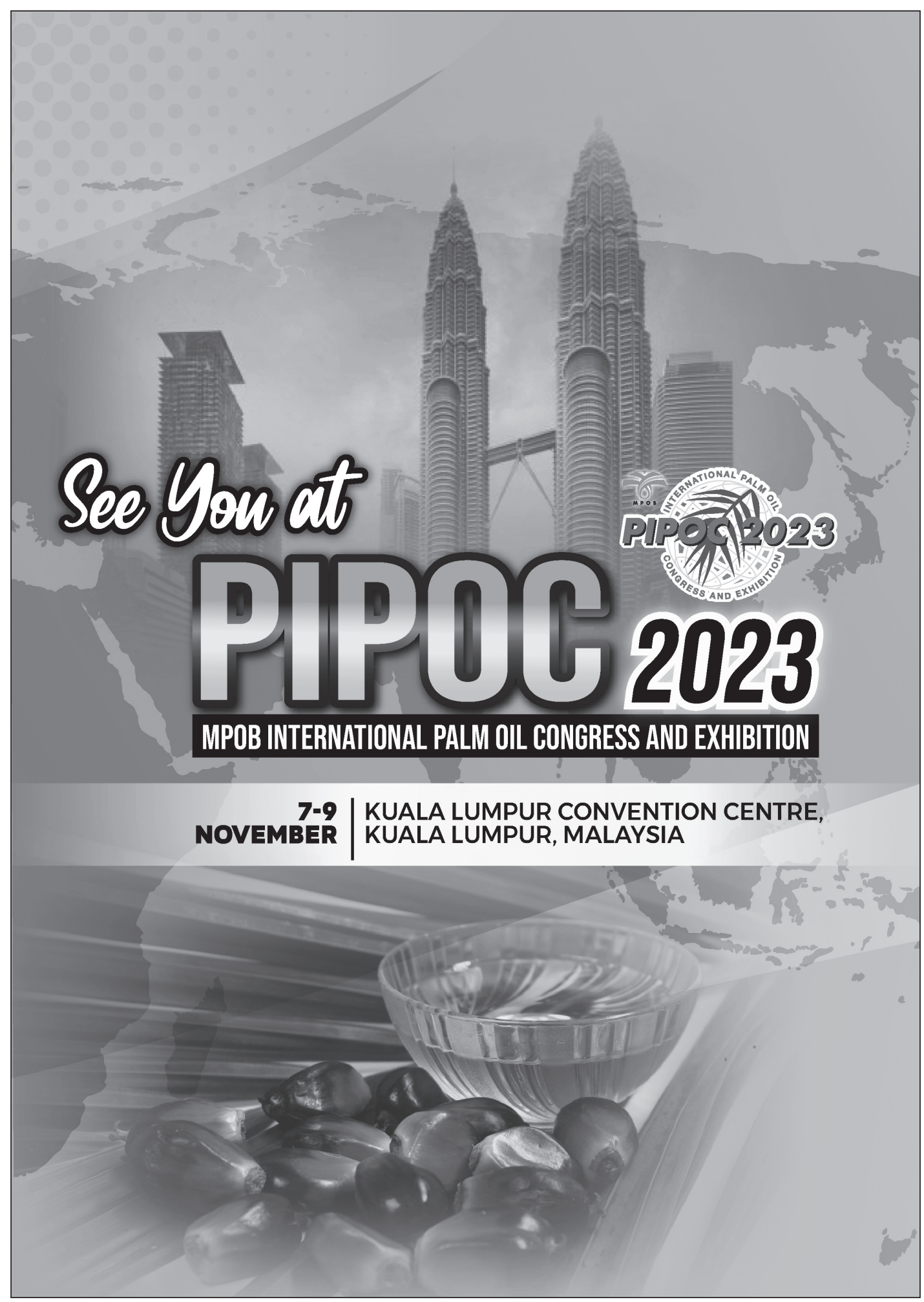

